\title{
INTEGRATED REPORTING DISCLOSURE, BUSINESS COMPLEXITY AND FIRM VALUE
}

\author{
Seful Komar ${ }^{1}$ \\ sefulkomar@gmail.com \\ Nurmala Ahmar ${ }^{2}$ \\ Dwi Dwi Prastowo Darminto \\ Universitas Pancasila, Jakarta ${ }^{1,3}$ \\ STIE Perbanas, Surabaya ${ }^{2}$
}

Jl. Raya Lenteng Agung, Srengseng Sawah Jagaraksa, Jakarta Selatan, DKI Jakarta 12640

Jl. Nginden Semolo No.34-36, Ngenden Jangkungan, Kec. Sukolilo, Surabaya, Jawa Timur 60118

received: 28/3/2020; revised: 16/4/2020; approved: 28/4/2020

\section{Abstract}

This study empirically investigates the effect of disclosure elements of integrated reporting on firm value. Business complexity is used as a moderating variable in the effect of integrated reporting on firm value. A total of 189 samples of manufacturing companies registered on the Indonesia Stock Exchange in 2015-2017 met the criteria using the purposive sampling method. A multiple linear regression analysis using SEM-PLS program is employed as a data analysis tool. The results showed that integrated reporting has significant effect on firm value. Business complexity moderates the relationship of disclosure integrated reporting to firm value. The better quality of information disclosure from element of integrated reporting increases investor confidence thereby increasing firm value.

Keywords: business complexity; firm value; integrated reporting disclosure 


\section{INTRODUCTION}

The gap between the stock market value and book value shows that the capital market does not place confidence in the financial statements and promised cash flow (Gamayuni, 2012). A study conducted by the commercial research institute Ocean Tomo in 2016 in New York compared the market value and book value of 500 companies in the United States over four decades and proved a dramatic increase in the value of intangible assets that turned out to affect the firm value. In this case, the proportion of intangible asset value from firm value increasingly dominates which initially only 17 percent of firm value but in 1975 it became $84 \%$ of the total firm value in 2015 (Tomo.O., 2015 ).

This is similar to the conditions on the Indonesia Stock Exchange which show a significant difference between equity book value of and equity market value. The higher the frim value can be interpreted as the success of a firm in creating value for shareholders. In 2014 , on average, the company value of manufacturing industry measured by Tobin's q value was 2.39 . Whereas, in 2015 it decreased to 2.09 but in 2016 it experienced a return to 2.20 and in 2017 it rose to 2.23 . However, the market value of the manufacturing industry equity is basically greater than the book value of the firm's equity (https://www.idx.co.id/perusahaan-tercatat/ laporan-keuangan-dan-tahunan, 2017).

Significant differences between market value equities and book value equities indicate that information from financial statements alone is not enough for investors to explain the company value. It indicates that there are still a number of company assets that are not measured or recorded (Gamayuni, 2012).

In business reporting, traditional model reporting is an annual report that is separate from financial reports, environmental related reports, and reports related to social activities, and others (Jensen and Berg, 2012). These reports are usually published only for shareholders and fund providers where they have different goals (Simnett \& Huggins, 2015 ). Therefore, the traditional financial reporting model fails to provide comprehensive information for stakeholders because some want both, in this case, financial and non-financial information in one report (Serafeim, 2014). Basically companies that have good performance will convey clear information and provide better disclosure to stakeholders (Mashayekhi et al, 2013).

The traditional model of financial reporting that is currently widely used has been criticized since it is oriented and focused on short-term performance, value creation, and historical data (Hoque, 2017). At present, the trend of the company's financial reporting format has begun to develop into Integrated Reporting (IR). Integrated reporting is a process founded on integrated thinking that results in a periodic integrated report by an organization about value creation over time and related communications regarding aspects of value creation (IIRC, 2013). Integrated Reporting has the benefit of increasing transparency in company operations and information for external parties so that it will improve and facilitate corporate strategic decision making, improve performance and will increase stakeholder confidence in the short, medium and long term (Hsiao \& Kelly, 2018; McNally et al, 2017; Barth et al, 2017; IIRC, 2016). In addition, the integrated reporting model reporting is also able to increase the value of the company in the eyes of investors because information related to good governance is relevant to them and there are no additional costs related to access to information that is relevant to them (Mervelskemper \& Streit, 2016 ).

According to Martinez (2016), the integrated reporting model is able to increase investors' perceptions about the company's future cash flow despite failing to improve company information related to the environment. Meanwhile, Lee \& Yeo (2016) found a positive relationship between firm value and stronger integrated reporting in companies with higher organizational complexity. This shows that Integrated Reporting (IR) improves the quality of information in complex companies such as companies with high intangible assets, companies with diverse business segments or subsidiaries.

Research related to Integrated Reporting (IR) related to company value has been conducted. El Deeb (2019), Barth et al (2017), Lee \& Yeo (2016), Martinez (2016), Mervelskemper \& Streit (2016) find that integrated reporting disclosure has a significant effect on firm value, while research conducted by Churet \& Eccles (2014) and Suttipun (2017) find that integrated reporting disclosure has no effect on firm value.

Based on the above background this research was conducted with the aim to test and empirically explain the effect of integrated reporting on firm value and the effect of business complexity moderating the relationship between integrated reporting on firm value on manufacturing companies listed on IDX. The conceptual framework of this research is illustrated in Figure 1.

\section{METHOD}

This is a quantitative study that aims to answer exploratory, descriptive, explanatory and predictive research (Latan and Ghozali, 2016). The study population is manufacturing companies listed on the Indonesia Stock Exchange (IDX) in 2015-2017. Meanwhile, the research sample is a manufacturing company registered at IDX that is selected based on criteria in accordance with the researchers' requirements. A total of 189 samples met the criteria using the purposive sampling method. The sample selection technique in this study is non-probability 
sampling using purposive sampling. The sample criteria are (1) Manufacturing companies listed on IDX and publish audit reports and annual reports consistently from 2015-2017. (2) The financial statements are presented in Rupiah (3) The company did not experience losses during the observation year (4) Having the ability of information related to the calculation of variables in this study.

The data collection is carried out through literature study and documentation methods. This research uses secondary data. Research data will be taken from the site www.idx.co.id. The operationalization of the variables is shown in Table 1 . Then, the data analysis is done through descriptive statistics. While testing this research hypothesis applies Partial Least Squares Structural Equation Modeling (PLS-SEM) analysis with SEM WARPLS 6.0 tools.

To obtain the best model from testing the research variables, this study employs three analytical models as follows.

$\mathrm{NP}=\alpha+\beta 1 \mathrm{SKORIR}+\varepsilon$

$\mathrm{NP}=\alpha+\beta 1 \mathrm{SKORIR}+\beta 2 \mathrm{COMPLEX}+\varepsilon$

$\mathrm{NP}=\alpha+\beta 1$ SKORIR $+\beta 2$ COMPLEX $+\beta 3$ SKORIR $*$ COMPLEX $+\varepsilon$

\section{Description:}

$\begin{array}{ll}\mathrm{NP} & : \text { Firm value } \\ \mathrm{A} & : \text { Constant } \\ \mathrm{B} & \vdots \text { Regression coefficient } \\ \varepsilon & : \text { Error } \\ \mathrm{SKORIR} & : \text { Index score of integrated reporting } \\ \text { COMPLEX } & : \text { Business complexity } \\ \text { SKO..*COM..: } & \text { IR interaction and business complexity }\end{array}$

\section{RESULT}

The descriptive statistical test results in Table 2 show that the company value variable in Tobin's $q$ has a minimum value of 0.228 and a maximum value of 23.286 while the mean value is 2.221 . It shows that in general the sample of this study has a good firm value above one. It indicates that the firm's market equity value is above its book value equity. The standard deviation value is 3.093 or above the mean value indicating that the sample data for Tobin's q has a tendency of diverse data.

The variable disclosure integrated reporting (IR) has a minimum value of 0.13 and a maximum of 0.865 . The mean value is 0.395 , which generally indicates that the sample of this study in general is still a few that adopt the implementation of integrated reporting of 39.5 percent or below 50 percent. The standard deviation value is 0.14 or below the mean value which indicates that the IR value data in the study sample has a tendency for data that does not vary. Then, the moderating variable of business complexity is a dummy variable.
The research hypothesis testing was conducted using the Partial Least Squares-Structural Equation Modeling (PLS-SEM) method. There are two evaluation models in PLS which consist of Outer Model and Inner Model. The Inner Model serves to show the estimated power between latent or construct variables. The outer model functions to show how the manifest or observed variable forms the latent variable to be measured (Latan and Ghozali, 2016). Table 3 and table 4 present the test results of the outer and inner models.

Table 3 shows that the composite reliability value, Cronbach's Alpha and the average variance extracted value of the company value has a value of more than 1,000. Assessment with Full Collinearity VIF has a mean value of 3.121 or still within the required limits of less or equal to 5 so that it passes the outer model test.

The results of Table 4 show that the indicator value of fit model of ARS, APC, AARS is $\mathrm{P}<0.001$ which is stated as significant because it meets the criteria of $p$-value $<0.05$. Then AVIF and AFVIF meet the multicollinearity requirements below 5 . In addition, other indicators such as GoF, RSCR, and NLCBDR meet the inner model test criteria.

Based on testing of the three research models, there are no significantly different results between models 1 and 2 but quite different from the model 3 shown in Table 6. The third model shows the best model compared to the second and the first model with an R-Squared Adj value of 0.394 or $39.4 \%$ which indicates that the independent variable integrated reporting and business complexity is able to explain the dependent variable of the company's value of $39.4 \%$ while the remaining $60.6 \%$ is explained by other variables outside the study. Meanwhile, the second model has an Adj R-Squared value of 0.288 and the first model of 0.266 .

Based on the results of the hypothesis test in Table 5 , integrated reporting has a significant effect on firm value in all models with a $\mathrm{P}$ value $<0.001$ where the first, second and third models are at a significance level of 1 percent. Business complexity moderates the relationship of integrated reporting to firm value with $P$ value $<0.001$ in the third model with a significance level of 1 percent. Based on the results of the hypothesis test in Table 5, the business complexity variable is a quasi-moderator since it interacts significantly with the firm value variable (dependent) and interacts with the integrated reporting (independent) variable

\section{DISCUSSION}

The results of testing the first hypothesis indicate that the integrated reporting disclosure elements affects the company value. The effect arising from the disclosure of integrated reporting on firm value is positive. It shows that the more widely management discloses the integrated reporting model in its annual report, the higher the firm value. The results of the first 
hypothesis indicate that the management of the frim that is used as a research sample discloses elements of integrated reporting which is one way to increase the firm value so that it looks good to the investors.

The results of this study are in line with the signal theory that explains that firm management provides signals in the form of information about the condition and performance of the firm to owners or interested parties through disclosure of accounting information. The better the disclosure of the quality of accounting information, the better the quality of the delivery of signals from that information so that it increases the relevance of the value of information. One form of signals sent is transparency through the disclosure of integrated reporting elements in the company annual report to investors to show that they are better than other firms and facilitate the company's strategic decision making. The increased transparency will increase stakeholder confidence. This is carried out by the company to attract investment and improve its image and reputation, which in turn has a positive impact on the company value. The results of this study also indicate that not only financial performance factors can increase company value but non-financial information also has an impact on increasing company value.

The results are in line with the results of research conducted by El Deeb (2019), Barth et al (2017), Lee \& Yeo (2016), Mevelskemper \& Streit (2016), and Martinez (2016) which prove that the integrated reporting disclosure model has an effect on company value. It is different from the results of research conducted by Churet \& Eccles (2014) and Suttipun (2017) who found the results that integrated reporting disclosure had no effect on firm value.

The results of the second hypothesis test show that business complexity moderates the relationship of integrated reporting disclosure to firm value. It shows that the existence of business complexity can be a trigger for the effect of the integrated reporting disclosure relationship on firm value.

Theoretically, firms that have a high level of business complexity will be a driving force for company management in adopting the application of integrated reporting models that are useful in internal corporate decision making and as relevant information for other stakeholders, especially investors in decision making. It ultimately increases the company performance and value. The results of testing the third hypothesis show that the level of complexity of the business affects the relationship of the application of the integrated reporting model to company value because investors and stakeholders pay attention to business complexity as a material for decision making or is relevant information and can increase company value. In this case, business complexity can contain various risk opportunities. It appears in the direction of the negative influence resulting from this hypothesis test which indicates that investors or other stakeholders tend to see that companies that have a large level of business complexity have greater risks than the performance opportunities that will be generated.

The results of this study are in line with research conducted by Barth et al (2017), Lee \& Yeo (2016) which states that business complexity moderates the relationship of integrated reporting disclosure to firm value.

\section{CONCLUSION}

This study aims to test and empirically explain the effect of the disclosure of integrated reporting model elements on firm value by moderating business complexity in manufacturing companies listed on IDX in the 2015-2017 period. Based on the analysis of research data and the results of the discussion, it was concluded that the integrated reporting model had a significant effect on firm value. Then, business complexity affects firm value and moderates the relationship of integrated reporting to firm value.

The limitation of this research is the measurement of integrated reporting disclosure variables using content analysis. Thus, it contains a high subjectivity element where rigid integrated reporting variable measurement formula has not been found and research samples in manufacturing companies are still limited. Future studies can try to use other method of integrated reporting disclosure measurement such as using the firm's capital perspective method according to IIRC and broaden the scope of research samples in other industries.

\section{REFERENCE}

Barth, M. E., Cahan, S. F., Chen, L., \& R., V. E. 2017. The economic consequences associated with integrated report quality: Capital market and real effects. Accounting, Organizations and Society, 62(2017), 43-64. https://doi.org/10.1016/j. aos.2017.08.005

Churet, C., \& Eccles, R. G. 2014. Integrated Reporting, Quality of Management, and Financial Performance. Journal of Applied Corporate Finance, 26(1), 8-16. https://doi.org/10.1111/jacf.12054

El Deeb, M. S .2019. The Impact of Integrated Reporting on Firm Value and Performance: Evidence from Egypt. Alexandria Journal of Accounting Research. Faculty of Commerce, Alexandria University, Volume No.3, Issue 2, ISSN: $2682-3144$

Gamayuni. 2012. Relevansi Kinerja Keuangan, Kualitas Laba, Intangible Asset, dengan Nilai Perusahaan. Trikonomika, 11(2), 119-136.

Hoque, M. E. 2017. Why Company Should Adopt Integrated Reporting. International Journal of Economics and Financial Issues, 7(1), 241-248. https://doi.org/http://dx.doi. org/10.1108/17506200710779521 
Hsiao, P.K. \& Kelly, M. 2018. Investment Considerations and Impressions of Integrated Reporting: Evidence from Taiwan. Sustainability Accounting, Management and Policy Journal, 9(1), 2-28.

IIRC. 2016., Creating Value - The cyclical power of integrated thinking and reporting, IIRC - The International Integrated Reporting Council.

IIRC. 2013. The International Integrated Reporting Framework

Jensen, J. C., and Berg, N. 2012. Determinants of Traditional Sustainability Reporting Versus Integrated Reporting. An Institutionalist Approach. Business Strategy and the Environment, 21(5), 299-316. https://doi.org/10.1002/bse.740

Latan, Hengky and Ghozali, Imam. 2016. Partial Least Square : Konsep, Metode dan Aplikasi Mgenggunakan WarpPLS 5.0 edisi 3. Semarang: Badan Penerbit Universitas Diponegoro.

Lee, K. W., \& Yeo, G. H. H. 2016. The association between integrated reporting and firm valuation. Review of Quantitative Finance and Accounting, 47(4), 12211250. https://doi.org/10.1007/s11156-015-0536-y

Martinez, C. 2016. Effects of Integrated Reporting on the Firm's Value: Evidence from Voluntary Adopters of the IIRC's Framework. Ssrn, (Papers.ssrn.com), 1-37. https://doi.org/10.2139/ssrn.2876145

Mashayekhi, B., Faraji, O., and Arash, T. 2013. Accounting Disclosure, Value Relevance and Firm
Life Cycle: Evidence from Iran. International Journal of Economic Behavior and Organization, 1(6), 6977. https://doi.org/10.11648/j.ijebo.20130106.13

McNally, M.A., Cerbone, D. and Maroun, W. 2017, Exploring the challenges of preparing an integrated report. Meditari Accountancy Research. Vol. 25 No. 4, pp. 481-504.

Mervelskemper, L., \& Streit, D. 2016. Enhancing Market Valuation of ESG Performance: Is Integrated Reporting Keeping its Promise? Business Strategy and the Environment, 26(4), 536-549. https://doi. org/10.1002/bse. 1935

Serafeim, G. 2014. Integrated Reporting and Investor Clientele. In Harvard Business School Working Paper (pp. 1-45). https://doi.org/10.2139/ ssrn.2378899

Simnett, R., \& Huggins, A. L. 2015. Integrated reporting and assurance: where can research add value? Sustainability Accounting, Management and Policy Journal, 6(1), 29-53. https://doi.org/http://dx.doi. org/10.1108/02683940010305270

Suttipun, M. 2017. The effect of integrated reporting on corporate financial performance: Evidence from Thailand. Corporate Ownership and Control, 15(1), 133-142. https://doi.org/10.22495/cocv15i1art13

Tomo. O., 2015. Ocean Tomo's Intangible Asset Market Value Study, Ocean Tomo Announces Result of Annual Study of Intangible Asset Market Value

Table 1. Variable Operationalization

\begin{tabular}{|c|c|c|c|}
\hline Variable & Indicators & Measurement & Scale \\
\hline \multirow{2}{*}{$\begin{array}{l}\text { Firm value } \\
\text { (Y) }\end{array}$} & \multirow{2}{*}{$\begin{array}{l}\text { - Market price value } \\
\text { - Market book value } \\
\text { - Total debt }\end{array}$} & Market equity value+Total Debt & \multirow[t]{2}{*}{ Ratio } \\
\hline & & Book equity value+Total Debt & \\
\hline
\end{tabular}

(Barth et al, 2017)

(Barth et al, 2017)

\begin{tabular}{|c|c|c|c|}
\hline $\begin{array}{l}\text { Integrated } \\
\text { Reporting } \\
\text { (X) } \\
\text { (Lee and } \\
\text { Yeo, 2016) }\end{array}$ & $\begin{array}{l}\text { Content analysis of eight } \\
\text { element of IR framework } \\
\text { - Overview of the } \\
\text { organization and } \\
\text { external environment } \\
\text { - Governance } \\
\text { - Business model } \\
\text { - R i s k s a n d } \\
\text { opportunities } \\
\text { - Strategy and } \\
\text { resource allocation } \\
\text { - Performance } \\
\text { - Outlook } \\
\text { Basis of presentation } \\
\end{array}$ & $\begin{array}{l}\qquad \text { IRSCORE }=(8 \text { Element of IR x } 5 \text { questions } x(0-5 \text { Point }) \text { ) } \\
\text { (Lee and Yeo, 2016) } \\
\text { Our construction of the IRSCORE is essentially a content analysis of integrated } \\
\text { reporting disclosure based on the IIR Framework. In each major content element, } \\
\text { we outline } 5 \text { questions to measure the comprehensiveness and quality of the IR } \\
\text { disclosure based on the principles embedded in the IIR framework. We evaluate the } \\
\text { information provided in response to each of the question on a scale of } 0 \text { to } 5 \text { where } \\
0 \text { represents non-compliance with principles and } 5 \text { represents strong compliance } \\
\text { with principles. Hence, the minimum score per each major content element is } 0 \\
\text { (comprising } 5 \text { questions x } 0 \text { point per question) and the maximum score per each } \\
\text { major content element is } 25 \text { (comprising } 5 \text { questions x } 5 \text { points per question). We } \\
\text { repeated this scoring algorithm for all } 8 \text { major content elements. Hence, the final } \\
\text { aggregated IRSCORE ranges from a minimum of } 0 \text { points (comprising } 0 \text { points } \\
\text { per each major content element } x 8 \text { major content elements) to a maximum of } 200 \\
\text { points (comprising } 25 \text { points per major content element x } 8 \text { major content elements) }\end{array}$ & Nominal \\
\hline $\begin{array}{l}\text { B us iness } \\
\text { complexity } \\
\text { (M) } \\
\text { (Lee and } \\
\text { Yeo, 2016) }\end{array}$ & $\begin{array}{l}\text { Number of subsidiaries } \\
\text { in a certain period }\end{array}$ & $\begin{array}{l}\text { Dummy Variable } \\
\text { Score }=1 \text { if the number of sample subsidiary companies is above the sample } \\
\text { median value score }=0 \text { if the number of sample subsidiaries is below the sample } \\
\text { median value } \\
\text { (Lee and Yeo, 2016) }\end{array}$ & \\
\hline
\end{tabular}


Table 2. Output of statistic descriptive

\begin{tabular}{lccccc}
\hline \multicolumn{1}{c}{ Proksi } & N & Min & Max & Mean & Std. Dev \\
\hline TOBINSQ & 189 & 0,288 & 23,286 & 2,221 & 3,093 \\
IR & 189 & 0,135 & 0,865 & 0,395 & 0,145 \\
COMPLEX* $^{*}$ & 189 & 0 & 1 & 0,392 & 0,489 \\
\hline
\end{tabular}

*dummy variable

Source: SEMWarpPLS 6.0

Table 3. Outer model output

\begin{tabular}{lcccc}
\hline \multicolumn{1}{c}{ Indikator } & IR & NP & COMPLEX & COMPLEX*IR \\
\hline Composite reliability & 1,000 & 1,000 & 1,000 & 1,000 \\
Cronbach's alpha & 1,000 & 1,000 & 1,000 & 1,000 \\
Avg. Var. Extrac. & 1,000 & 1,000 & 1,000 & 1,000 \\
Full collin. VIF & 1,721 & 1,208 & 1,678 & 1,218 \\
\hline Source: SEMWarpPLS 6.0 & & &
\end{tabular}

Table 4. Inner model output

\begin{tabular}{lllccc}
\hline \multirow{2}{*}{ No } & & \multicolumn{2}{c}{ Indicators } & Criteria & \multicolumn{2}{c}{ output } & \multirow{2}{*}{ Remarks } \\
\cline { 3 - 5 } & & P-value $<0,05$ & P-value & Index & \\
\hline 1 & Average R-Squared (ARS) & P-value $<0,05$ & $\mathrm{P}<0,001$ & 0,394 & Accepted \\
2 & AdjR-Squared (AARS) & P-value $<0,05$ & Accepted \\
3 & Average Path Coef (APC) & $\leq 5$, ideally $\leq 3,3$ & 0,343 & Accepted \\
4 & AVIF (Avg.Block Variance Inflation Factor) & $\leq 5$, ideally $\leq 3,3$ & 1,124 & Accepted \\
5 & AFVIF (Avg. Full Collinearity VIF) & W $\geq 0,1 ; \mathrm{M} \geq 0,25 ; \mathrm{S} \geq 0,36$ & 1,456 & Accepted \\
6 & Tenehaus GoF (GoF) & Acceptable if $\geq 0,7$ & 0,636 & Strong \\
7 & RSCR (R-Squared Contribution Ratio) & & 0,989 & Accepted \\
8 & NLBCDR (Nonlinear Bivariate Causality Direction Ratio) & Acceptable if $\geq 0,7$ & 0,833 & Accepted \\
\hline
\end{tabular}

Source: SEMWarpPLS 6.0

Tabel 5. Result of Hypotesis Testing

\begin{tabular}{llcccccc}
\hline \multirow{2}{*}{ No. } & \multirow{2}{*}{ Variable } & \multicolumn{2}{c}{ Model 1 } & \multicolumn{2}{c}{ Model 2 } & \multicolumn{2}{c}{ Model 3 } \\
\cline { 3 - 7 } & & p-value & path coeff & p-value & path coeff & p-value & path coeff \\
\hline 1 & IR & $<0,001 * * *$ & 0,52 & $<0,001 * * *$ & 0,583 & $<0,001 * * *$ & 0,581 \\
2 & COMPLEX & & & 0,007 & $-0,173$ & 0,055 & $-0,114$ \\
3 & COMPLEX*IR & & & & $<0,001^{* * *}$ & $-0,334$ \\
& R-Squared & 0,27 & 0,296 & & 0,404 & \\
& Adj R-Squared & 0,266 & & 0,288 & & 0,394 & \\
\hline
\end{tabular}

The dependent variable of firm value (Tobins $Q$ )

$*, * *, * * *$ show the significance at the level of $0.10 ; 0.05$ and 0.01

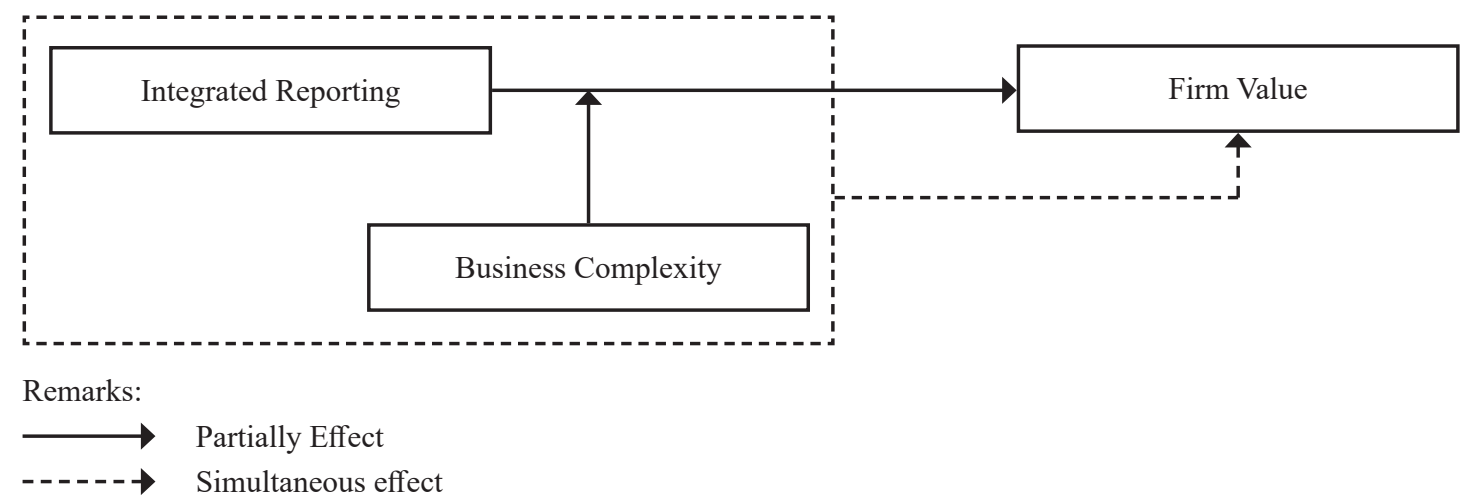

Figure 1. Conceptual Framework 